\title{
The Research on Core Competence of Furniture Company
}

\author{
Liu Liwen \\ The college of Economics and Business administration, Beijing Jiaotong University
}

\begin{abstract}
Chinese furniture industry has beco- me the world's furniture manufacturing center after a rapid period of development in the past 25 years. China also has become the world's largest furniture pr- oduction and export country. However, most of the furniture enterprise haven't strong competitiveness. How to enhance the competitiveness and cultivate the core competence of furniture enterprise has become the focus of discussion by furniture industry and academia. This paper will diiscuss how to identify and cultivate the core cometence from the concept and characteristics of the core competence combined with the characteristics of the furniture industry, then study how to improve the core competence with Diamond Model.
\end{abstract}

Index Terms - Core Competence, Furniture, Diamond Model

\section{The Concept and Characteristics of the Core Competence}

Core competence is combination of a series of complementary skills and knowledge of an or- ganization, it has the ability to make one or more business to reach the first-class level in compe- titive field. The core competence is the resource of the enterprise, which relates to strategy, innova- tion, talent, management, culture, marketing, production, services, etc. It is also the commo- $\mathrm{n}$ behavior of business departments and staff.

Core competence has the following four cha-racteristics:

1) Value. The core competence has strate- gic value, it brings the key benefits for custo- mers and creates long-term competitive initiative and excess profit, which exceed average profit of the industry, for company.

2) Unique. The core competence is only possessed by the company. There is almost no another company that has exactly the same or similar core competitiveness.

3) Ductility. The core competence will support company to expand the new promising business, it is a kind of ability to adapt to market changes.

4) Inimitable and irreplaceable. The core competence is the ability to integrate the internal resources, skills and knowledge of the company, which is difficult to imitate and replace for competitors. Otherwise, its unique characteri- stics will not exist and the competitive advant- age will disappear.

\section{How to Identify the Core Competence}

Business is a combination of unique resou- rces and capabilities. resources include human resources, material resources and organization resources. Single resource cannot form a lasting competitive advantage. Resources will become strategic resources when machine, equip- ment and other relevant factors can effective- ly become an organism. An organization forms the competitive advantage by combinating and integrating a series of resources. Ability is the result of integrating a series of resources. Not all of the resources and capabilities have the potential to become sustainable competitive adv- antages. The ability will become continued core competence when this ability is valuabl- e, rare, imperfectly imitable and nonsubstituta- ble. According to the four characteristics of the core competence, it can be identified easily.

\section{Study How to Improve the Core Competence with Diamond Model.}

According to the diamond model theory of core competitiveness, the corporation core competence depends not only on the level of an essential factor such as corporate culture, human resources, innovation, organization, marketing, strategic planning, management, production and service ability, but also on the degree of mutual interrelations and influence among these factors, each one factor has close connection with the other six factors, as shown in fig.1:

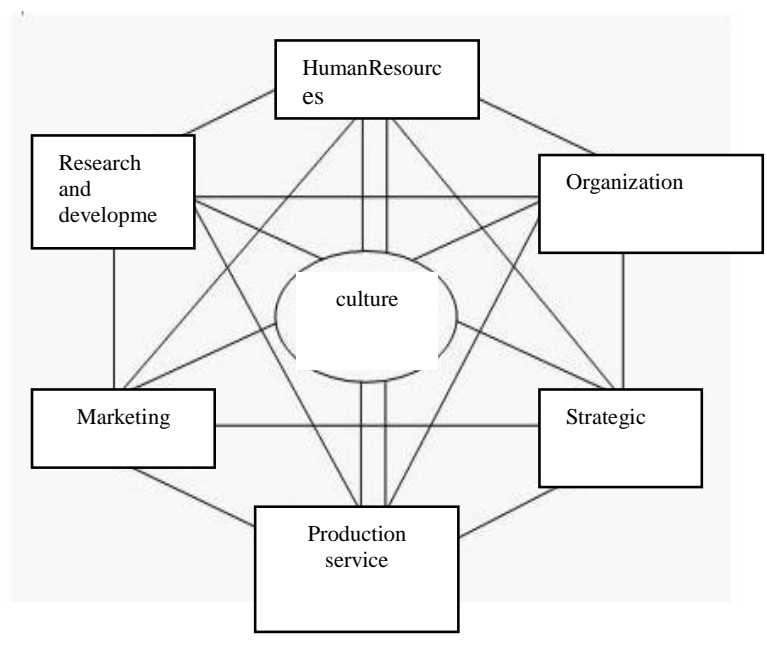

Fig. 1 Core competitiveness Diamond Model

Now, we analyze the source of furniture corporation core competence based on diamond model, which provides the reality basis for the furniture enterprise to enhance competitive- ness.

1) How to construct the furniture enterprise culture.

Enterprise culture is not only helpful to improve the productivity of enterprises and economic benefits, but also conducive to the survival and development of enterprises. Advanced corporation culture is the core comp- etence of enterprise, which is difficult to be completely imitated and exceeded by competit- ors. So the best strategy of furniture enterprise is to establish advanced corporation culture according to their own conditions and environment. 
Most of the furniture enterprise managers lack the awareness of enterprise culture, some of them think the enterprise culture is very emp-ty, there is no way to start the construction of enterprise culture, the others think the enterprise culture is the collection of banners and slogans, so there are so many slogan hanging in every corner of the office, most of slogan is philosophical statements speaking in excitement emotion. the building of enterprise cult- ure that is divorced from reality, not get staff's understanding and recognition, the effect of which is very poor.

The enterprise culture is invisible to all, but it should follow some rules. Firstly, to d-etermin the mind identity which includes staf-f values, enterprises spirit and business purpos-e. Enterprise value is the primary task and main content of enterprise culture construction, it's gradually formed in the long-term proce-ss of enterprise production and operation act-ivities. Secondly, to establish visual identity, which include trademarks, brand, packaging, a-dvertising, clothing, stationery, bags, disposable cups, printed, and all other elements of visu-al identity. Furniture enterprises should focus -on the management of the store, exhibition h-all and the procuct model, showing to consu-mers in a unified logo and image. Thirdly, the furniture enterprises should establish the beha-vior identity, mainly reflected in the propaganda, education, training of internal staff, forei-gn business, and social responsibilities. Busin-ess philosophy combined pratice guide the b-ehavior of enterprises and employee. Finally, t-o create spiritual through humanistic manage-ment, to build material culture through high quality product image, to construct institution-al culture by strict and harmonious manage-ment, thus forming advanced enterprise cultu-re of furniture enterprises.

The building of enterprise culture is a d-ynamic process with the development of ente-rprise development, not accomplish at one str-oke, is the essence of enterprises accumulate-d in the development process.

\section{2) Human resources}

Chinese furniture industry is labor-intensi-ve industries. But the coastal city has appeare-d the phenomenon of labor shortage and r-ecruitment difficult by the impact of the sup-ply of human resources, this phenomenon w-ill be more common and in the future ind-ustrial development process. shortage of hu-man resources has become an unavoidable to-pic in furnitue industry. At the same time, to-tal labor demand is increasing in furture ind-ustry. However, high labor intensity, noise, po-llution and risk gradually reduce the enthusi-asm of the labor market to this industry. Ent-erprises should realize this point and improve the degree of mechanization. Obviously, the furniture corporation didn't do like this, b-ut to eacavate human resource by high cos-t. Chinese furniture industry not only lack de-sign talent, but also lack core technological -personnel and professional management pers-onnel. It means that the whole industry is ba-ckward and affect the development of enterp-rises in the aspects of decision-making, polic-y, management, marketing strategy etc. Anoth-er way to get core competence of enterprises is to strengthen the construction of human -resources.

\section{3) Research and development}

There are more than 60 million employ-ees and less than 3 thousand professional d-esigners in chinese furniture industry. Furnit-ure province Guangdong has more than 6000 furniture enterprises, but less than 600 prof-essional designers, that means the ability of research and innovation in furniture industry is pretty poor. Why does the furniture indus-try lack creative power? The main reasons -are not attach importance to talents, poor w-orking environment, low social treatment. No high-level professional designer means no -original design. Imitation and plagiarism bet-ween furniture corporations lead to products homogenization. Furniture enterprises should cultivate many professional designers and in-crese investment in research and development to update product. It's an inevitable trend t-o drive the development of furniture industry with advanced design in the future. One so-urce of core competence is to strengthen the ability of $\mathrm{R} \& \mathrm{D}$.

\section{4) Production and service ability}

From the level of indusrial equipment of the domestic funiture enterprises, there are almost no one corporation arrived advanced stage of industrialization which means the p-roduction line should be completely automat-ic, digital, information and have modern ind-ustrial system. Most of them are still in the primary stage of industrialization which mix with hand and semi-automatic production line. Although some enterprises imported automa-tic production line, the information and digit-al has not kept pace with it. So there are low efficiency of production and large amount of labor cost in chinese furniture industry. It's hard to achieve the scale of economies effect.

Service system not only refers to intruduce product patiently and carefully, delivery, installation, but also include maintenance and repair products, old furniture processing schemes. Perfect service system can keep contacts between consumers and business, then cosumers will know more and more about companies and more likely to be loyal customers. Strong production capacity and perfect service system will bring competitive advantage to the furnitue company.

\section{5) Marketing}

The lack of consumer brand cause low marketing efficiency, brand marketing should be paid enough attention in the furniture in-dustry. There are thousands of brands in c-hinese furniture industry, but no one brand form a distinctive brand image in the minds of consumers. Some of the famo- us brand can only know its name, not a very perceptual image. Some business onwers think brand is equivalent to high grade and price, ingoring the brand popularity. Brand from high-end to popularization request the enterprise to reduce cost, reasonable planning, constant cummunication with consumers, so that there are a brand in mind before consumer puechase it. Chinese furniture market need many popular brand with independent intel- lectual rights. Other way to enhance the marketing ability is to build strategic alliance and construct strong marketing team. 
6) Strategic management

There are large number of companies in chinese furniture industry because of low tec- hnological content, less capital investment and not too high barries to entry. According to incomplete statistics, there are more than 60 thousand companies in chinese furnitue industry, most of them are small and medium enterprises, some of them are small family workshops. Some small and medium enter- prises success by chance, courage and the imblance of seller's market, with no strategic planning and low-level management. But now there are so many challenges and large competition pressure. Business onwers and senior managers form development strategy in a comprehensive grasp of macro environment, industry environment and micro environment combined its own conditions.

7) Organization and management

Furniture enterprises have the characteristic of extensive management just like many other domestic small and medium companies. There are only a few of senior managers who are multitasker with cross departmental functions. There will be more and more specialized departments and functional positions in man- agement system formed on experience with the development of enterprises. Some of them are overlap or defect because of the responsibility of positins without systematic arrangement and clearly defined. It will directly lead to low management efficiency, hard to communication and cooperation cross different department. The goal of Individuals, departments and corporations are often not consistent. Then it is difficult to achieve the goals of entreprise and departments. Therefore, furniture companies should clearly define the key departments and main responsibilities of senior manager to avoid overlap and defect positions. Clearly defined responsibilities will deepen the under- standing of responsbility and objectives, rationally allocate the limited resources, fully mobilize the enthusiasm and initiative of staff.

\section{Conclusion}

We can get the following conclusion based on the above analysis.

Furniture enterprises should construct distinct corporate culture that can be accepted and approved by all the staff and establish the perfect mechanism of talent resource development which can fully mobilize the enthusiasm and initiative of staff. Furniture enterprises must pay more attention to cultivate excellent designers and to the introduction of advanced equipment and technology to ensure product quailty and the benefits of companies. Strong brands will improve the efficiency and effect- iveness of marketing, so brand building is very important for furniture companies. Raising the level of strategic management and the necessary organizational change are also helpful to cultiv- ate core competence.

\section{References}

[1] Yin Yongheng, Elementary analysis about the important role of the design of chinese modern furniture in the product market positioning. In the literary life: in newborns, 2010(9).

[2] Zhang Mingyu, Management, Science Press, 2007.

[3] Chang Le, About how to enhance the competitiveness of furniture industry. Chinese wood-based panel, 2011(10)

[4] Zhang Wensong, Stretegic management- to gain competitive advantage. Machinery Industry Press

[5] Deborah Leslie, Suzanne Reimer. Fashioning furniture: Restructuring the furniture commodity chain. Area, 2003, 35(4):427-437.

[6] Xiao Han, Yali Wen, Shashi Kant.The global competitiveness of the Chinese Wooden furniture industry. Forest Policy and Economics, 2009(11): 561-569. 